\title{
Supply Contract Intelligence : The Impact of Stockout and Overstock Experiences Using System Dynamics Simulation Model
}

\author{
Yonghwi Noh \\ School of Business Administration, \\ Myongji University, Seoul, Korea \\ (acipco@hanmail.net) \\ Jin Sung Rha \\ Department of Management, University of \\ Nebraska-Lincoln, Lincoln, NE, USA \\ (rhajinsung@gmail.com)
}

\author{
Donghyun Choi \\ Department of Management \\ Kansas State University, KS, USA \\ (darenchoi@gmail.com) \\ Yongkee Suh \\ Section manager, Logisall Corporation, \\ Seoul, Korea \\ (yongkeesuh@hanmail.net)
}

The purpose of this study is to investigate the influence of behavioral factors (buyer's tendency to reflect stockout and overstock experiences in ordering decision) on the supply chain performance. This study employs system dynamics to examine the influence of these behavioral factors derived from the interview with several representatives of retailers in South Korea. The results show that different contract can bring different performance (total profit, seller's profit, buyer's profit, order quantity, sales quantity, overstock, and stockout). The results also suggest that these behavioral factors play a significantly influential role in the performance of supply contract. These results imply that supply contract should be established based on the analysis of behavioral factors of supply chain participants.

Received : May 08, 2013 Revision : June 03, 2013 Accepted : June 10, 2013

Type of Submission : English Fast-Track Corresponding author : Yonghwi Noh

\section{Introduction}

In recent years, supply chain management has become more important due to increased business complexity has raised environmental uncertainty. Along with increased complexity in business environment, buying firms have been outsourcing more functions to their suppliers. Thus, coordination between buyers and suppliers has become one of the key success factors in the competition between suppliers. The disruption between buyer and supplier not only causes excessive operating cost, but also decreases stock value, finally causing the harmful effects on the capital structure of a firm (Hendricks and Singhal, 2005). Therefore, in order to have coordination 
among supply chain members, many researchers have studied various features of supply contract over the years (Cachon and Lariviere, 2005; Dejonckheere et al., 2003; Granot and Yin, 2005; Gonçalves et al., 2005; Kim et al., 2012; Lee et al., 2012; Pasternack, 1985; Suh et al., 2012; Tsay, 1999). However, there is a paucity of research on the impact of a firm's experiences of stockout and overstock of its inventory on the next ordering decision. Since decision makers make decision with bounded rationality, they cannot order optimized quantity based on all the information. Decision makers are mostly influenced from their previous experience (Simon, 1991). This experience can cause significant impacts on the total value of the whole supply chain as well as the profits of individual firm in the long run.

Therefore, focusing on the impact of stockout and overstock experiences of the supply chain participants, this study tries to find which type of contracts has positive impact on performance of the firm according to different situation. We model the newsvendor model for simulation and compared this base model with buyback contract model and revenue sharing model to investigate the effect of each contract. Comparing the results, we first quantify the value of being able to contract on quality to the buyer. This value, which is obtained from interview, provides an upper bound on the value of activities that the supplier can produce. Buyback and revenue sharing contract are employed, because they are one of the most frequently used contracts as the alternative models to improve the performance of supply chain and known to increase the total value of whole supply chain (Pasternack, 1985; Cachon and Lariviere, 2005). The purpose of this study is to investigate how stockout and overstock experiences affect the profit of market participants and performance variables in supply chain for both short term and long term. To do this, system dynamics program, Vensim DSS 5.6 is used. We compared buyback and revenue sharing model with no contract model.

This paper is organized as follows: in the next section, review of relevant literature is presented. Then, the research model and methodology to identify the effect of stockout and overstock experiences are shown. In the following section, the results of the simulation using system dynamics are presented based on each contract model and period of time. Finally, this paper concludes the results of simulation with implication of the results, limitation of this study, and future research needs.

\section{Review of Relevant Literature}

\subsection{Coordinating Supply Chain with Contract}

Appropriate supply contracts are significant to maintain and improve the utilization of an organization to achieve superior performance (Farrell and Shapiro, 1989; Scott, 1987). Especially under today's dynamic business environment, efficiency in relationship between suppliers and buying firm, locked in competitive prices and quantities for particular contractual terms, can create indispensable competitive advantages in a company's supply chain (Nellore and Motwani, 
1999). In this vein, a variety of issues in supply contract have been studied so far. The issues of previous studies regarding supply contracts can be classified into six categories: specification of decision rights, pricing, buyback, quantity flexibility, minimum purchase commitments, and allocation (Tsay et al., 1998).

Among these categories, the first analytical research about buyback policy was performed by Pasternack (1985). He stated that the return policy to buy back a particular ratio of an original transaction without the limitation of the buyback quantity can influence the total value of supply chain (Pasternack, 1985). From the perspective, Kandel (1996) expanded Pasternack's (1995) study and insisted that only the return policy without autonomous price control among supply chain partners cannot properly coordinate the supply chain. In addition, he stated that the impact of other variables such as retailer's efforts for promotion, information asymmetry, and elasticity of market demand should be considered in terms of the degree of risk aversion of supply chain partners (Kandel, 1996).

The studies about quantity flexibility have focused on how much power to control order quantity should be given to purchasers. By increasing order quantity flexibility, sellers can predict minimum level of order quantity and buyers can evade the uncertainty of customers' demands. As a result, the total profits of whole supply chain can be increased by quantity flexibility (Tsay, 1999). Also, by minimum purchase agreement, suppliers can get the insight about the minimum purchase amount with lower price for products. This contract can also increase total performance of whole supply chain network (Bassok and Anupindi, 1997).

\subsection{Types of Supply Contracts}

A few alternative contracts have been studied to improve the performance of whole supply chain given the standard newsvendor model such as buyback contract (Pasternack, 1985), quantity flexibility contract (Tsay, 1999), sales rebate contract (Taylor, 2002), and revenue sharing contract (Cachon et al., 2005). This study starts with the standard newsvendor model in which a manufacturer sells products to independent purchasers facing uncertain demands and extends it by applying the characteristics of buyback contract and revenue sharing contract, assuming stockout and overstock experiences.

Under buyback contract, suppliers accept returns of unsold products for full or partial credits by the negotiation with purchasers who face random demand. In North America, a variety of products such as newspapers, CDs, dairy products, costume jewelry, books, fashion wear, computer products, recordings, and peripherals are usually permitted to buyback to their source for full or partial credits (Granot and Yin, 2005). Buyback contract can coordinate the basic newsvendor model in which a supplier provides products to a buyer for a fixed wholesale price and a fixed buyback ratio, and a buyer faces a fixed retail price, stochastic demand (Pasternack, 1985). 
Under revenue sharing contract, purchasers pay suppliers discounted prices for the products purchased, plus a certain level of revenue the purchasers gain. This contract has become more popular in the video cassette rental industry relative to the conventional wholesale price contracts (Cachon and Lariviere, 2005). The estimated increase of total profits in this industry by revenue sharing contracts were up to 7\% (Mortimer, 2008). The revenue sharing model was also able to coordinate the standard newsvendor model (Cachon and Lariviere, 2005).

\subsection{Supply Chain Instability}

As supply chain is getting more complex and more various members are involved, most organizations are seeking healthful supply chain. In this regard, many literatures investigate activities on supply chain and critical factors to acquire organization's competitive advantages. Although strategies and behaviors in supply chain have ameliorated, many firms still have difficulties in controlling their inventories accurately and effectively, bringing supply chain instability (Gonçalves et al., 2005). The bullwhip effect in supply chain, sometimes called whiplash effect, occurs due to distorted communications between suppliers and demanders, the communications including demand forecast updating, order batching, price fluctuation, and rationing and shortage gaming (Lee et al., 1997. Especially, in the bullwhip effect larger variance of suppliers than sales to the demanders may make inventories of both suppliers and demanders out of control (Lee et al., 2004).
Fisher et al. (1997) suggests that organizations need to take into account supply chain disruptions, the mismatches between suppliers and demanders, in terms of economic effect. Supply chain management, in many cases, often place the low cost first rather than stable supply chain (Kilgore, 2003). Dejonckheere et al. (2003) suggest that since the instability is fate, firms have to focus on forecasting unstable demand and relevant environment. Especially supply chain disruptions can reduce shareholder values and increase the equity risk in that organizations do not get over the disruptions immediately (Hendricks and Singhal, 2005). In terms of stocks, supply chain instability has an effect on inventory levels including overstock and stockout (Gonçalves et al., 2005). To solve the instability, suppliers and demanders need to consider coordination such as information sharing, channel alignment, and operational efficiency (Lee et al., 1997). Narayanan and Raman (2004) indicate that a supply chain is not functioning unless the risks, costs, and rewards of sales are unfair across the chain and that this misalignment lead to excess inventory, stock-outs, incorrect forecasts, inadequate sales efforts, and poor customer service. However, according to Cachon (2004), channel alignment like coordinating contract is not a panacea since this alignment definitely costs more to manage than a single wholesale price contract costs to implement, monitor and supervise.

\subsection{System Dynamics Approach}

The system dynamics approach is designed 
by Forrester (1961). By using the structure and dynamics feedback sequence in heterogeneous field many social behaviors can be systematically analyzed (Forrester, 1961). In addition, Forrester (1961) points out that system dynamics focus on the multi-loop, multistate, nonlinear features in complex world. System dynamics modeling is composed of feedback loops, accumulation processes, and delays between cause and effect (Sterman, 2000). Especially, system dynamics approach is able to play an important role to investigate supply chain because system dynamics define its components as many SC activities includeing the reverse logistics, the distorted information flow, the initiating inventories, the effect of bottle necks, and the hipment delays (Grßler et al., 2008). Mass (1980) and Sterman (2000) illustrate that as far as stocks concern, system dynamics is critical approach because stocks reflect the state of the system and when making decision, managers often use accumulated data from stocks information as a criterion. Also they suggest that system dynamics characterize the source of delay and the differences between inflow and out flow.

\section{Research Model}

To discuss important issues in setting parameters, we interviewed representatives of three firms in different industries. Each reprehensive reviewed our basis assumptions and agreed with model. Since system dynamics is a useful approach to understand feedback from complex decision making process in the supply chain, we selected system dynamics as a simulation method and VENSIM DSS 5.6 was used. The model has three basic assumptions: (1) Supply chain in our model is operated by one seller and one buyer. (2) A buyer places an order with a seller by analyzing an end customer's demand. (3) A seller supplies its products to fulfill order from a buyer.

\subsection{Exogenous Variables}

To build up the simulation model, we set up exogenous variables: actual demand, seller's cost, wholesale price, price, and salvage cost. We use the random normal function to reflect distribution of the demand in newsvendor model. We assume that demand is independent of whether or not the consumer would like to buy the good. We generated random normal varieties with Minimum 1000, Maximum 5000, Average 3000, and Standard Deviation 1000 based on interviews.

Actual Demand $=$ RANDOM NORMAL $(1000,5000,3000,1000$, seed)

Values of the rest exogenous variables were adopted based on the interview with representative retailers in their industries.

$$
\begin{aligned}
& \text { Seller's Cost }=\$ 35 \\
& \text { Wholesale Price }=\$ 75 \\
& \text { Price }=\$ 125 \\
& \text { Salvage Cost }=\$ 25
\end{aligned}
$$

\subsection{Basic Newsvendor Model}

Since the demand in news vendor model 


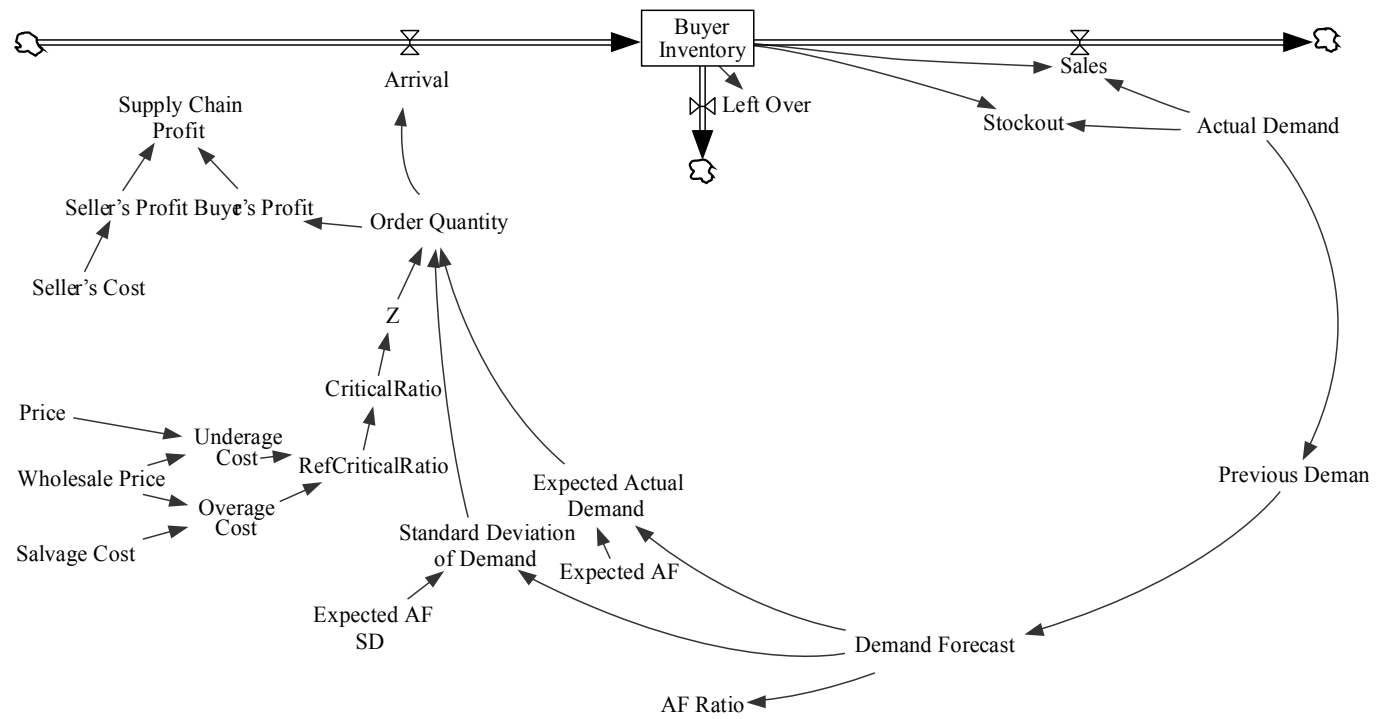

$<$ Figure 1> Basic Newsvendor Model

has uncertain characteristic, we take a random normal function to reflect the uncertain demand. Suppliers forecast demand using data from the past. We adopted the moving average method as the approach to forecasting demand and the demand is based on the past actual demand for a week. Basic newsvendor model is shown in $<$ Figure $1>$.

Suppliers take into account not only differences between actual and forecasting demand (A/F ratio) but also economic costs to determine their order quantity.

Order Quantity $=$ Expected Actual Demand $+\mathrm{Z} \times$ Standard Deviation of Demand

In the newsvendor model, left inventory will be transformed into savage cost. Thus, in the model, buyer's profit is calculated as:
Buyer's Profit = MIN (Buyer Inventory, Actual Demand) $\times$ Price-Wholesale Price $\times$ Order Quantity + Salvage Cost $\times$ Left Over

We estimated supplier's profit using three parameters:

Supplier's Profit $=$ Wholesale Price $\times$ Order Quantity - Supplier's Cost $\times$ Order quantity

Buyer's Profit added to seller's profit makes supply chain profit.

\subsection{Newsvendor Model with Stock-out and Overstock}

There has been minimal research regarding the functional relation of the effect of left over and stock out experience on order quantity. So, we draw permissible adjustment rate by carrying 
out simulation on the assumption that each members on supply chain behave in an effort to maximize their profit.

We assumed that permissible rate of leftover adjustment is a constant, which determines, when buyers adjust their order quantity in terms of left over experience, certain order rates comparing with left over experience. Likewise, in case that buyer adjusts order quantity in terms of stock out experience, permissible rate of stock-out adjustment is a constant value that determines certain order rates comparing with stock-out experience. Newsvendor model with stockout and overstock is shown in $<$ Figure $2>$.

Left over adjustment on order quantity is determined by comparing previous order quantity with permissible rate of leftover adjustment.
THEN ELSE (Left Over $>=$ (Previous Order Quantity $\times$ Permissible rate of leftover adjustment), Left Over - (Previous Order Quantity $\times$ permissible rate of leftover adjustment), 0 )

Like left over adjustment, stock-out adjustment is calculated by comparing two parameters, previous order quantity and permissible rate of stock-out adjustment.

Stock-out adjustment on order quantity $=\mathrm{IF}$ THEN ELSE (Stock Out $>=$ (Previous Order Quantity $\times$ Permissible rate of Stock Out adjustment), Stock Out - (Previous Order Quantity $\times$ permissible rate of Stock Out adjustment), 0)

In this regard, effect of adjust on order quantity can be expressed:

Left over adjustment on order quantity $=$ IF

Effect of Adjustment on Order Quantity =

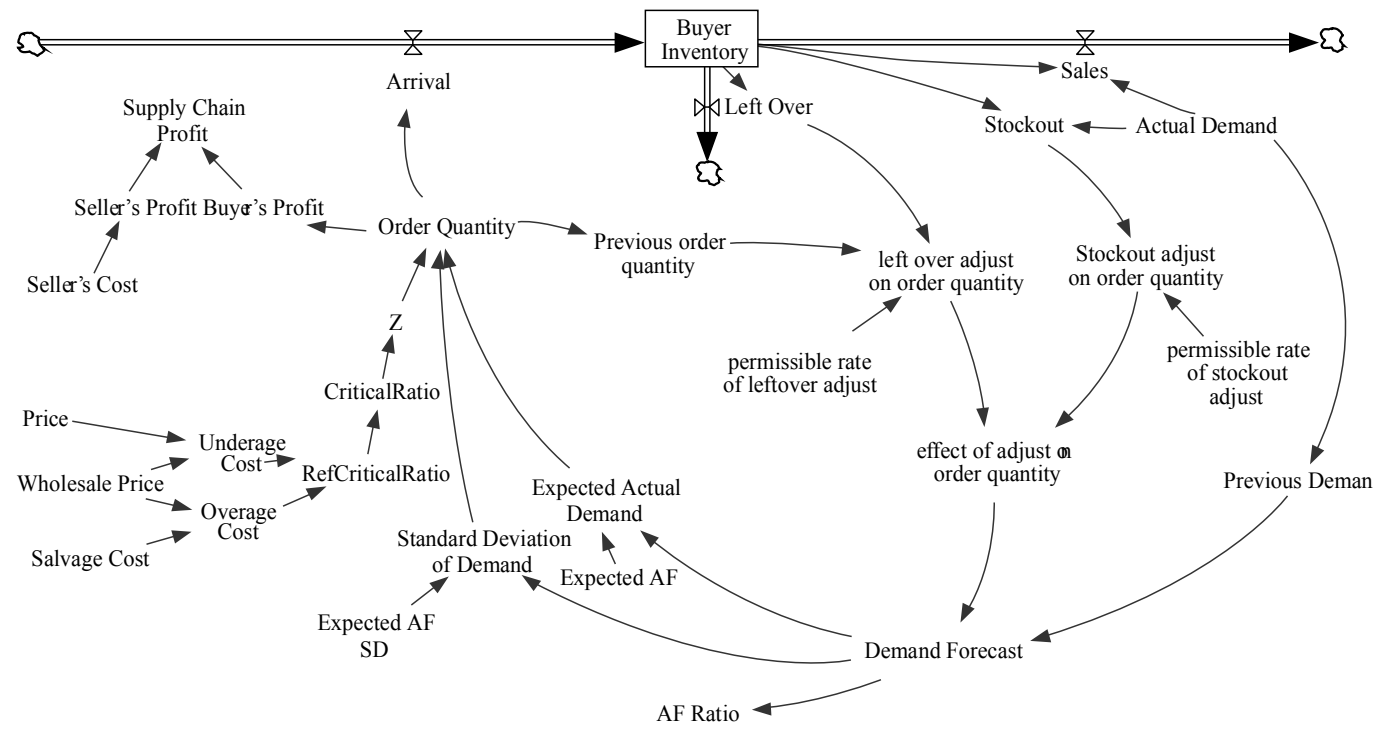

<Figure 2> Newsvendor Model with Stockout and Overstock 
- left over adjustment on Order Quantity + Stock Out adjustment on Order Quantity

As shown in $<$ Table $1>$, by using scenario method we calculated the permissible rate, which maximizes buyer's profit. We put five permissible rates, $30 \%, 40 \%, 50 \%, 60 \%, 70 \%$, into each supply contract model and simulated 10 times.

$<$ Table 1> Permissible Rate Maximizing Buyer's Profit

\begin{tabular}{|c|c|c|}
\hline & $\begin{array}{c}\text { Permissible Rate } \\
\text { of Stockout }\end{array}$ & $\begin{array}{c}\text { Permissible Rate } \\
\text { of Overstock }\end{array}$ \\
\hline Price Only & $70 \%$ & $40 \%$ \\
\hline Buyback & $30 \%$ & $60 \%$ \\
\hline Revenue Sharing & $30 \%$ & $60 \%$ \\
\hline
\end{tabular}

\subsection{Buyback Model}

Under buyback contracts, the buyer pays the wholesale price and repayment from seller, which is for any unsold items, is guaranteed. Buyback model is presented in $<$ Figure $3>$. In buyback contract, we calculated buyback profit, buyer's profit, and seller's profit as:

Buyback Price $=$ Price $-($ Price - Wholesale Price) / ((Price-Salvage Cost) / (Price - Seller's Cost))

Buyer's Profit = MIN (Buyer Inventory, Actual Demand) $\times$ Price - Wholesale Price $\times$ Order Quantity + Buyback Price $\times$ Buyback Quantity

Seller's Profit $=$ Wholesale Price $\times$ Arrival - Seller's Cost $\times$ Arrival - Buyback Quantity $\times$ Buyback Price + Buyback Quantity $\times$ Salvage Cost

\subsection{Revenue Sharing Model}

A revenue sharing contract indicates that a buyer pays a supplier both a wholesale price and

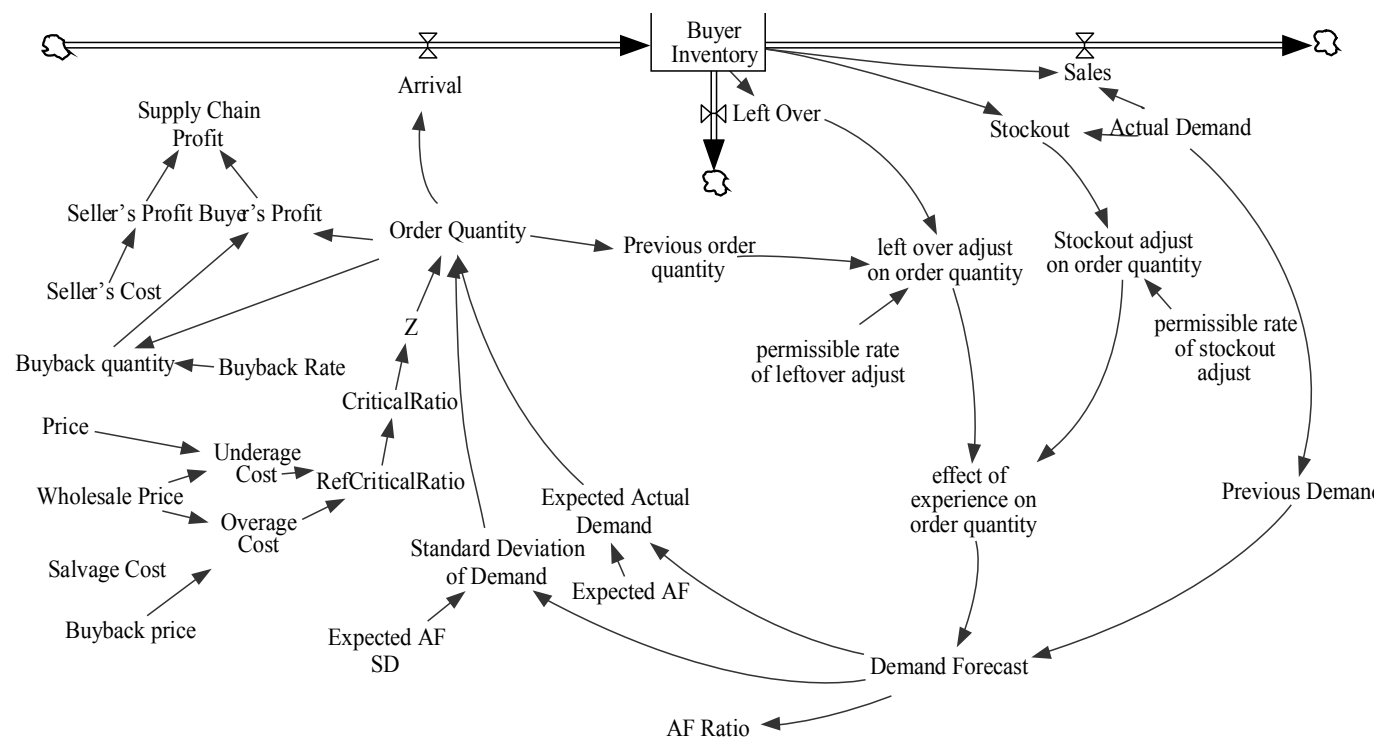

$<$ Figure 3> Buyback Model with Stockout and Overstock 
$<$ Table 2> Supply Chain Performance of Each Contract Model with Stockout and Overstock

\begin{tabular}{|c|c|c|c|c|c|c|c|c|}
\hline & Total Profit & $\begin{array}{c}\text { Seller's } \\
\text { Profit }\end{array}$ & $\begin{array}{c}\text { Buyer's } \\
\text { Profit }\end{array}$ & $\begin{array}{c}\text { Order } \\
\text { Quantity }\end{array}$ & $\begin{array}{c}\text { Sales } \\
\text { Quantity }\end{array}$ & Overstock & Stockout \\
\hline Price Only & Mean & 20.802 & 12.403 & 8.371 & 310,887 & 265,769 & 31,895 & 44,961 \\
& SD & 0.7716 & 0.3945 & 0.4196 & 9,872 & 9,603 & 3,027 & 2,846 \\
\hline \multirow{2}{*}{ Buyback } & Mean & 22.079 & 12.680 & 9.399 & 414,826 & 291,830 & 5,835 & 121,725 \\
& SD & 0.7933 & 0.4308 & 0.4346 & 12,345 & 10,110 & 1,574 & 4,115 \\
\hline Revenue & Mean & 21.177 & 12.397 & 8.780 & 345,544 & 273,832 & 23,832 & 71,430 \\
Sharing & SD & 0.8172 & 0.4724 & 0.3854 & 14,010 & 10,440 & 2,498 & 6,718 \\
\hline
\end{tabular}

surplus of a rate of the revenue that the buyer makes.

Revenue sharing model is presented in $<$ Figure $4>$. Wholesale price, buyer's profit, and seller's profit can be expressed:

Wholesale Price $=$ Existing Wholesale Price - Wholesale Price Discount

Buyer's Profit $=(\mathrm{MIN}$ (Buyer Inventory, Actual Demand) $\times$ Price - Wholesale Price $\times$ Order Quantity + Salvage Cost $\times$ Left Over $) \times(1-$ Profit Sharing Rate)
Seller's Profit $=$ Wholesale Price $\times$ Order Quantity - Seller's Cost $\times$ Order Quantity + Profit Sharing Rate $\times$ Buyer's Exprofit

\section{Result of the Study}

\subsection{Results of Supply Chain Performance with Stockout and Overstock}

In our research, there are three contract models: price only, buyback, and revenue sharing model considering stock out and over stock. We

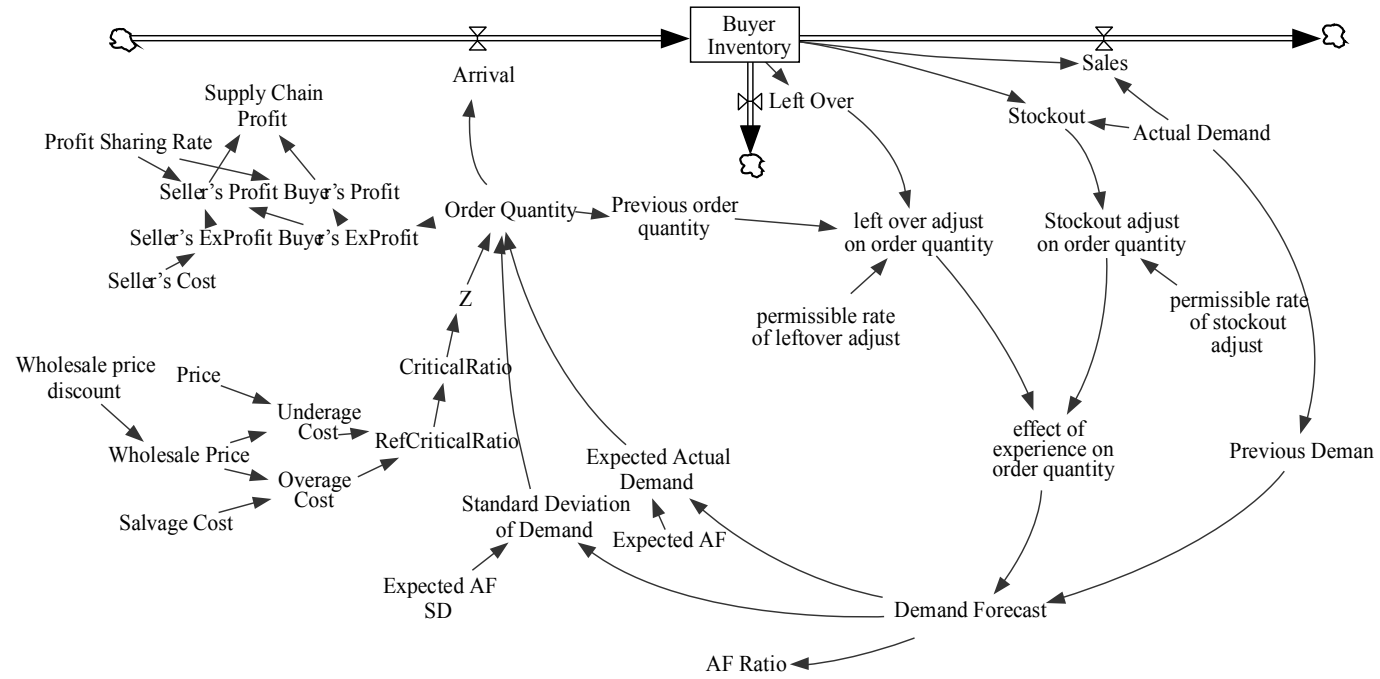

$<$ Figure 4> Revenue Sharing Model with Stock-out and Overstock 
simulated contract models reflecting stock out and over stock in order to check performance parameters (supply chain profit, seller profit, buyer profit, order quantity, sales, stockout, and overstock). Each contract models was simulated 200 times independently. The results are presented in <Table $2>$.

In buyback model shown in $<$ Table $3>$, reflecting stock out and over stock, three profit parameters including supply chain profit, seller's profit, and buyer's profit are significantly bigger than those in price only contract model reflecting stock out and over stock.

$<$ Table 3> Comparison of Price Only with Buyback Contract

\begin{tabular}{|c|r|r|r|c|}
\hline & $\begin{array}{c}\text { Mean } \\
\text { Difference }\end{array}$ & t-value & Df & $\begin{array}{c}\text { Sig. } \\
(2-\text {-tailed })\end{array}$ \\
\hline Total Profit & -1.277 & -9.519 & 199 & 0.00000 \\
\hline Seller's Profit & -0.250 & -15.983 & 199 & 0.00306 \\
\hline Buyer's Profit & -1.029 & -3.232 & 199 & 0.00000 \\
\hline Order Quantity & -103.940 & -50.847 & 199 & 0.00000 \\
\hline Sales Quantity & -26.060 & -15.220 & 199 & 0.00000 \\
\hline Overstock & 26.060 & 54.597 & 199 & 0.00000 \\
\hline Stockout & -76.763 & -127.337 & 199 & 0.00000 \\
\hline
\end{tabular}

According to $<$ Table $4>$, in revenue sharing model reflecting stock out and over stock, seller profit significantly increased, but buyer profit and supply chain profit did not change.

Comparing with price only model considering stock out and over stock, both buyback and revenue sharing model reflecting stock out and over stock have more stock out, order quantity, and sales but less overstock. The results are shown in $<$ Table $5>$.
$<$ Table 4> Comparison of Price Only with Revenue Sharing Contract

\begin{tabular}{|c|r|r|c|c|}
\hline & $\begin{array}{c}\text { Mean } \\
\text { Difference }\end{array}$ & t-value & Df & $\begin{array}{c}\text { Sig. } \\
\text { (2-tailed) }\end{array}$ \\
\hline Total Profit & -0.375 & -2.085 & 199 & 0.04595 \\
\hline Seller's Profit & 0.033 & 0.346 & 199 & 0.73221 \\
\hline Buyer's Profit & -0.410 & -0.410 & 199 & 0.00015 \\
\hline Order Quantity & -34.657 & -13.115 & 199 & 0.00000 \\
\hline Sales Quantity & -8.063 & -3.560 & 199 & 0.00130 \\
\hline Overstock & 8.063 & 14.760 & 199 & 0.00000 \\
\hline Stockout & -26.469 & -22.775 & 199 & 0.00000 \\
\hline
\end{tabular}

$<$ Table 5> Changes in Performance

\begin{tabular}{|l|c|c|c|c|c|c|c|}
\hline & $\begin{array}{c}\text { Total } \\
\text { Profit }\end{array}$ & $\begin{array}{c}\text { Seller's } \\
\text { Profit }\end{array}$ & $\begin{array}{c}\text { Buyer's } \\
\text { Profit }\end{array}$ & $\begin{array}{c}\text { Order } \\
\text { Quantity }\end{array}$ & $\begin{array}{c}\text { Sales } \\
\text { Quantity }\end{array}$ & $\begin{array}{c}\text { Oversto } \\
\text { ck }\end{array}$ & Stockout \\
\hline Buyback & + & + & + & + & + & - & + \\
\hline $\begin{array}{c}\text { Revenue } \\
\text { Sharing }\end{array}$ & $\begin{array}{c}\text { No } \\
\text { change }\end{array}$ & $\begin{array}{c}\text { No } \\
\text { change }\end{array}$ & + & + & + & - & + \\
\hline
\end{tabular}

$<$ Table 6> Comparison of Buyback with Revenue Sharing Contract

\begin{tabular}{|c|c|c|c|c|}
\hline & $\begin{array}{c}\text { Mean } \\
\text { Difference }\end{array}$ & t-value & Df & $\begin{array}{c}\text { Sig. } \\
\text { (2-tailed) }\end{array}$ \\
\hline Total Profit & 0.903 & 3.866 & 199 & 0.00057 \\
\hline Seller's Profit & 0.619 & 5.294 & 199 & 0.00001 \\
\hline Buyer's Profit & 0.283 & 2.154 & 199 & 0.03972 \\
\hline Order Quantity & 69.283 & 18.785 & 199 & 0.00000 \\
\hline Sales Quantity & 17.297 & 6.048 & 199 & 0.00000 \\
\hline Overstock & -17.997 & -41.401 & 199 & 0.00000 \\
\hline Stockout & 50.295 & 34.622 & 199 & 0.00000 \\
\hline
\end{tabular}

As presented in $<$ Table $6>$, buyback model made more seller profit and supply chain profit, in comparison to revenue sharing model. Also buyback increased order quantity, sales, and stockout more than revenue sharing. There is no difference of buyer profit between two models. 


\subsection{Comparison with Supply Chain Performance without Stockout and Overstock}

We compared the performance of supply contract without stockout and overstock experiences with that of supply contract with those experiences. The results are presented in $\langle$ Table 7$\rangle$, $<$ Table $8>$, and $<$ Table $9>$.

With these results, we employed t-test to examine the significance of the influence which the stockout and overstock experiences have on the supply chain performance. For this analysis, we simulated each model for 200 times. As presented in $\langle$ Table 10$\rangle$, in price only contract (basic newsvendor model), significant difference was found in buyer's profit, which means that the buyer's behavior to maximize its profit leads to substantial increase in profit. In contrast, reflecting the stockout and overstock experiences decreased seller's profit and the profit of whole supply chain. As a whole, the experiences have a negative impact on the whole supply chain performance. The stockout and overstock experiences also decreased the order quantity of buyer, leading to the decrease of sales quantity and overstock, and the increase of stockout.

$<$ Table 7> Performance Comparison in Price Only Contract

\begin{tabular}{|c|c|c|c|c|c|c|c|c|}
\hline & Total Profit & $\begin{array}{c}\text { Seller's } \\
\text { Profit }\end{array}$ & $\begin{array}{c}\text { Buyer's } \\
\text { Profit }\end{array}$ & $\begin{array}{c}\text { Order } \\
\text { Quantity }\end{array}$ & $\begin{array}{c}\text { Sales } \\
\text { Quantity }\end{array}$ & Overstock & Stockout \\
\hline Without & Mean & 20.889 & 12.559 & 8.3295 & 314,118 & 267,120 & 46,797 & 30,545 \\
Experience & SD & 0.7796 & 0.4014 & 0.4392 & 10,021 & 9,688 & 3,436 & 3,014 \\
\hline With & Mean & 20.802 & 12.430 & 8.371 & 310,887 & 265,769 & 44,961 & 31,895 \\
Experience & SD & 0.7716 & 0.3945 & 0.4196 & 9,872 & 9,603 & 2,846 & 3,027 \\
\hline
\end{tabular}

$<$ Table 8> Performance Comparison in Buyback Contract

\begin{tabular}{|c|c|c|c|c|c|c|c|c|}
\hline & Total Profit & $\begin{array}{c}\text { Seller's } \\
\text { Profit }\end{array}$ & $\begin{array}{c}\text { Buyer's } \\
\text { Profit }\end{array}$ & $\begin{array}{c}\text { Order } \\
\text { Quantity }\end{array}$ & $\begin{array}{c}\text { Sales } \\
\text { Quantity }\end{array}$ & Overstock & Stockout \\
\hline Without & Mean & 22.058 & 11.103 & 10.95 & 418,773 & 292,046 & 125,383 & 5,619 \\
Experience & SD & 0.7966 & 0.3973 & 0.4010 & 12,735 & 10,141 & 5,082 & 1,760 \\
\hline With & Mean & 22.079 & 12.680 & 9.399 & 414,826 & 291,830 & 121,725 & 5,835 \\
Experience & SD & 0.7933 & 0.4308 & 0.4346 & 12,345 & 10,110 & 4,115 & 1,574 \\
\hline
\end{tabular}

$<$ Table 9> Performance Comparison in Revenue Sharing Contract

\begin{tabular}{|c|c|c|c|c|c|c|c|c|}
\hline & Total Profit & $\begin{array}{c}\text { Seller's } \\
\text { Profit }\end{array}$ & $\begin{array}{c}\text { Buyer's } \\
\text { Profit }\end{array}$ & $\begin{array}{c}\text { Order } \\
\text { Quantity }\end{array}$ & $\begin{array}{c}\text { Sales } \\
\text { Quantity }\end{array}$ & Overstock & Stockout \\
\hline Without & Mean & 22.071 & 13.241 & 8.830 & 418,151 & 292,094 & 124,793 & 5,573 \\
Experience & SD & 0.8684 & 0.5224 & 0.3473 & 13,709 & 11,035 & 5,860 & 2,021 \\
\hline With & Mean & 21.177 & 12.397 & 8.780 & 345,544 & 273,832 & 71,430 & 23,832 \\
Experience & SD & 0.8170 & 0.4724 & 0.3854 & 14,010 & 10,440 & 6,718 & 2,498 \\
\hline
\end{tabular}


$<$ Table 10> Results of t-test for Performance Variable in Price Only Contract

\begin{tabular}{|c|r|r|r|c|}
\hline & $\begin{array}{c}\text { Mean } \\
\text { Difference }\end{array}$ & t-value & Df & $\begin{array}{c}\text { Sig. } \\
(2 \text {-tailed) }\end{array}$ \\
\hline Total Profit & -0.087 & -7 & 199 & 0.00352 \\
\hline Seller's Profit & -0.129 & -20.10941 & 199 & 0.00000 \\
\hline Buyer's Profit & 0.040 & 3.17739 & 199 & 0.00000 \\
\hline Order Quantity & $-3,231$ & -21 & 199 & 0.00000 \\
\hline Sales Quantity & $-1,351$ & -10 & 199 & 0.00000 \\
\hline Overstock & $-1,836$ & -10.4937 & 199 & 0.00000 \\
\hline Stockout & 1,351 & 9.6939 & 199 & 0.00000 \\
\hline
\end{tabular}

In case of buyback contract shown in $<$ Table $11>$, buyer's profit significantly decreased after reflecting the stockout and overstock experiences, while seller's profit increased. The increase of seller's profit might result from the decrease of buyback risk. The profit of whole supply chain does not significantly change and it might be because the decrease of buyer's profit is almost same as the increase of seller's profit. The stockout and overstock experiences does not significantly affect the order quantity, sales quantity, and stockout, while overstock decreased.

$<$ Table 11> Results of t-test for Performance Variable in Buyback Contract

\begin{tabular}{|c|r|r|r|c|}
\hline & $\begin{array}{c}\text { Mean } \\
\text { Difference }\end{array}$ & t-value & Df & $\begin{array}{c}\text { Sig. } \\
(2 \text {-tailed })\end{array}$ \\
\hline Total Profit & 0.021 & 0.15892 & 199 & 0.87483 \\
\hline Seller's Profit & 1.577 & 19.7174 & 199 & 0.00000 \\
\hline Buyer's Profit & -1.550 & -23.38014 & 199 & 0.00000 \\
\hline Order Quantity & $-3,947$ & -1.740598 & 199 & 0.09236 \\
\hline Sales Quantity & -216 & -0.124174 & 199 & 0.90203 \\
\hline Overstock & $-3,658$ & -5.273242 & 199 & 0.00001 \\
\hline Stockout & 216 & 1.3029 & 199 & 0.20286 \\
\hline
\end{tabular}

The results for revenue sharing contract are presented in <Table 12>. In revenue sharing contract model, reflecting the stockout and overstock experience results in the significant decrease in seller's profit and whole supply chain's profit. Conversely, buyer's profit was not affected significantly. These experiences caused the order quantity, sales quantity, and overstock to decrease, while they increased the stockout.

$<$ Table 12> Results of t-test for Performance Variable in Revenue Sharing Model

\begin{tabular}{|c|r|r|c|c|}
\hline & $\begin{array}{c}\text { Mean } \\
\text { Difference }\end{array}$ & t-value & Df & $\begin{array}{c}\text { Sig. } \\
(2 \text {-tailed })\end{array}$ \\
\hline Total Profit & -0.894 & -3.441 & 199 & 0.00178 \\
\hline Seller's Profit & -0.843 & -5.548 & 199 & 0.00001 \\
\hline Buyer's Profit & -0.050 & -0.442 & 199 & 0.66165 \\
\hline Order Quantity & $-72,607$ & -18.047 & 199 & 0.00000 \\
\hline Sales Quantity & -18.262 & -5.541 & 199 & 0.00001 \\
\hline Overstock & $-53,363$ & -30.450 & 199 & 0.00000 \\
\hline Stockout & 18,260 & 30.382 & 199 & 0.00000 \\
\hline
\end{tabular}

\subsection{Summary of the Results}

The results of t-test for performance variables in each contract model are summarized in $<$ Table 13>. The stockout and overstock experiences decreases the total profit of price only and revenue sharing contract, while they do not affect the performance of buyback contract. In price only contract, the buyer's efforts to maximize its profits (efforts to reflect the stockout and overstock experiences) lead to not only the decrease of seller's profit but also the decrease of total profits of supply chain, although buyer obtains additional profit. In buyback contract, the experiences have no impact 
on total profit, positive impact on seller's profit, and negative impact on buyer's profit. In revenue sharing contract, total profit and seller's profit are affected negatively, while buyer's profit does not change.

$<$ Table 13> Results of t-test for Performance Variable in Revenue Sharing Model

\begin{tabular}{|c|c|c|c|}
\hline & $\begin{array}{c}\text { Price } \\
\text { Only }\end{array}$ & Buyback & $\begin{array}{c}\text { Revenue } \\
\text { Sharing }\end{array}$ \\
\hline Total Profit & - & No change & - \\
\hline Seller's Profit & - & + & - \\
\hline Buyer's Profit & + & - & No change \\
\hline Order Quantity & - & No change & - \\
\hline Sales Quantity & - & No change & - \\
\hline Overstock & - & - & - \\
\hline Stockout & + & No change & + \\
\hline
\end{tabular}

As a whole, the performance of supply chain deteriorates after reflecting the experiences of stockout and overstock. From the literature, we know that buyback contract can coordinate the price only model (Pasternack, 1985), and revenue sharing contract also coordinate the profits of whole supply chain (Cachon and Lariviere, 2005). However, the results of this study show that the performance of supply contract can be negatively affected by buyer's behavioral factors in buyback and revenue sharing contract. These results imply that behavioral factors of supply chain participants should be considered in establishing new supply contract.

\section{Conclusion}

This study delineates the influence of behavioral factors (buyer's tendency to reflect stockout and overstock experiences in supply contract) in price only, buyback, and revenue sharing contract. The results show that the performance variables (total profit, seller's profit, buyer's profit, order quantity, sales quantity, overstock, and stockout) were affected differently according to the supply contract models.

The results suggest that the use of buyback and revenue sharing contracts can negatively influence the performance of supply chain considering buyer's tendency to reflect stockout and overstock experiences in supply contract. In other words, supply contract which does not properly reflect behavioral characteristics of supply chain participants might decrease the performance of whole supply chain as well as individual participants' profits. These results imply that behavioral factors of supply chain participants should be considered in supply contract, because they play an influential role in the success of applying new types of supply contracts such as buyback and revenue sharing model. This distinguishing feature of our study allows us to capture the effects of behavioral factors that are difficult to capture with analytical model. For example, the analytical model assumes that the decision makers are rational, and their objective is to maximize expected utility. Human decision makers are known to violate such behavioral assumptions, which might affect their decision in actual situations. From our research model, we could find that reflecting behavioral factors can improve prediction of the contract performance when the various parameters change. 
This study has practical implications. First, firm managers can apply behavioral factors to their supply contracts based on this study. Through the simulation reflecting stockout and overstock experiences, they can improve their supply contract performance. Second, this study provides a useful tool to evaluate operating performance of the firm. Third, this study can help firm managers to decide the level of price discount or revenue sharing when they make supply contracts. Fourth, based on the results of this study, supply chain members can cooperate to improve the overall performance of the whole supply chain.

This study has a limitation in terms of external validity because the behavioral factors were derived from the interview with only a few retailers in South Korea. However, the results of this study can be generalized due to the fact that the interviewed retailers were the representative companies with high market share in their industries. In addition, this study employs only the stockout and overstock experiences as behavioral factors, even though there might be a variety of other behavioral factors which influence the performance of supply contract.

Despite these limitations, this study presents some contributions in terms of the fact that it shows the importance of behavioral factors in supply contract performance. If more supply contract models other than buyback and revenue sharing models are analyzed, it can shed more light on the influence of these factors. Also, further study on the other behavioral factors affecting supply contract performance might give some additional insight for developing appropriate supply contract.

\section{References}

Bassok, Y. and R. Anupindi, "Analysis of Supply Contracts with Total Minimum Commitment," IIE Transactions, Vol.29, No.5(1997), 373 381.

Cachon, G. P., "The Allocation of Inventory Risk in a Supply Chain : Push, Pull, and AdvancePurchase Discount Contracts," Management Science, Vol.50, No.2(2004), 222 238.

Cachon, G. P. and M. A. Lariviere, "Supply Chain Coordination with Revenue-Sharing Contracts : Strengths and Limitations," Management Science, Vol.51, No.1(2005), 30 44.

Dejonckheere, J., S. Disney, M. Lambrecht, and D. Towill, "Measuring and avoiding the bullwhip effect : A control theoretic approach," European Journal of Operational Research, Vol.147, No.3(2003), 567 590.

Farrell, J. and C. Shapiro, "Optimal Contracts with Lock-In," The American Economic Review, Vol.79, No.1(1989), 51 68.

Fisher, M., J. Hammond, W. Obermeyer, and A. Raman, "Configuring a supply chain to reduce the cost of demand uncertainty," Production and Operations Management, Vol.6, No.3 (1997), 211 225.

Forrester, J. W., Industrial Dynamics, Cambridge : MIT Press, MA, 1961.

Granot, D. and S. Yin, "On the Effectiveness of Returns Policies in the Price-Dependent Newsvendor Model," Naval Research Logistics, Vol.52, No.8(2005), 765 779.

Grßler, A., J. Thun, and P. Milling, "System Dynamics as a Structural Theory in Operations Management," Production and Operations Management, Vol.17, No.3(2008), 373 384.

Gonçalves, P., J. Hines, and J. Sterman, "The 
Impact of Endogenous Demand on Push-Pull Production Systems," System Dynamics Review, Vol.21, No.3(2005), 187 216.

Hendricks, K. and V. Singhal, "An Empirical Analysis of the Effect of Supply Chain Disruptions on Long-Run Stock Price Performance and Equity Risk of the Firm," Production and Operations Management, Vol.14, No.1(2005), 35 52.

Kandel, E., "The Right to Return," Journal of Law and Economics, Vol.39, No.1(1996), 329 356.

Kilgore, M., Mitigating supply chain risks. White paper, Chainalytics LLC, Atlanta, Georgia, 2003.

Kim, H., I. Son, and D. Lee, "The Viral Effect of Online Social Network on New Products Promotion : Investigating Information Diffusion on Twitter," Journal of Intelligence and Information Systems, Vol.18, No.2(2012), 107 130.

Lee, H., V. Padmanabhan, and W. Seungjin, "Information Distortion in a Supply Chain : The Bullwhip Effect," Management Science, Vol.50, No.12(2004), 1875 1886.

Lee, H., V. Padmanabhan, and S. Wang, "The Bullwhip Effect in Supply Chains," MIT Sloan Management Review, Vol.38, No.3(1997), 93 102.

Lee, J., I. Son, and D. Lee, "Does Online Social Network Contribute to WOM Effect on Product Sales?," Journal of Intelligence and Information Systems, Vol.18, No.2(2012), 85 105.

Mass, N., Stock and Flo Variables and the Dynamics of Supply and Demand, in Randers, J (ed.), Elements of the System Dynamics Method. Waltham, Pegasus Communications, MA, 1980.

Mortimer, J. H., "The effects of revenue-sharing contracts on welfare in vertically separated markets : Evidence from the video rental industry,"
Review of Economic Studies, Vol.75, No.1(2008), 165 199.

Narayanan, V. G. and A. Raman, "Aligning Incentives in Supply Chains," Harvard Business Review, Vol.82, No.11(2004), 94 102.

Nellore, R. and J. Motwani, "Procurement Commodity Structures : Issues, Lessons and Contributions," European Journal of Purchasing and Supply Management, Vol.5(1999), 157 166.

Pasternack, B., "Optimal Pricing and Return Policies for Perishable Commodities," Marketing Science, Vol.2(1985), 166 176.

Simon, H. A., "Bounded rationality and organizational learning," Organization science, Vol.2, No.1(1991), 125 134.

Scott, W. R., Organizations : Rational, Natural, and Open Systems, $2^{\text {nd }}$ Edition. Prentice-Hall International Edition, Englewood Cliffs, NJ, 1987.

Sterman, J. D., Business Dynamics : Systems Thinking and Modeling for a Complex World, Irwin-McGraw-Hill : Chicago, IL, 2000.

Suh, W., D. Lee, and K. Lim, "A Study on the Performance Evaluation of G2B Procurement Process Innovation by Using MAS : Korea G2B KONEPS Case," Journal of Intelligence and Information Systems, Vol.18, No.2(2012), 157 175.

Taylor, T., "Supply Chain Coordination under Channel Rebates with Sales Effort Effects," Management Science, Vol.48, No.8(2002), 992 $\sim 1007$.

Tsay, A. A., "The Quantity Flexibility Contract and Supplier-Customer Incentives," Management Science, Vol.45, No.10(1999), 1339 1358.

Tsay, A. A., S. Nahmias, and N. Agrawal, Modeling Supply Chain Contracts : A Review. Quantitative Model for Supply Chain Management, Kluwer, Boston, MA, 1998. 


\title{
Abstract
}

\section{공급사슬지능 : 시스템 다이나믹스를 이용한 재고 과부족 경험이 공급사슬에 미치는 영향 분석}

\author{
노용휘 ${ }^{*}$ 최동현 ${ }^{* *}$. 나진성*** 서용기 ${ }^{* * * *}$
}

본 연구는 재고 과부족 경험을 주문에 반영하고자 하는 구매자의 행동적 경향이 공급사슬의 성과에 미치는 영향에 대해 고찰하였다. 이를 위해 한국의 대표적인 소매점 몇 곳의 경영자와의 인터뷰 결과를 토대로 시스템 다이나믹스 시뮬레이션 기법을 사용하여 분석을 수행하였다. 공급사슬 전체 이익, 판매자 이익, 구매자 이익, 주문량, 판매량, 재고초과, 재고부족 등 다양한 공급사슬 성과 변수에 대한 분석 결과 서로 다른 공급 계약은 서로 다른 공급사슬의 성과를 가져왔다. 또한, 구매자의 행동적 요소는 공급계약의 성과에 중요한 영향을 미치고 있었다. 본 연구의 결과를 토대로 공급계약은 공급사슬 참여자들의 행동적 특성을 충분히 반영하여 수립되어야 함을 알 수 있다.

Keywords : 공급계약, 재고부족, 재고초과, 바이백, 수익공유, 시뮬레이션, 시스템 다이나믹스

\footnotetext{
* 명지대학교 경영학과 교수, 교신저자

** 캔사스 주립대 경영학과 Visiting Scholar

*** 네브래스카 주립대 경영학과 박사과정

**** (주) Logisall 매니저
}

36 지능정보연구 제19권 제2호 2013년 6월 


\section{저 자 소 개}

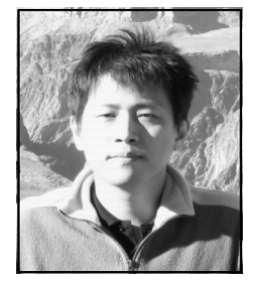

\section{Yonghwi Noh}

Yonghwi Noh is an assistant professor at the School of Business Administration, Myongji University in South Korea. He received a Bachelor degree at KAIST (Korea Advanced Institute of Science and Technology), a master degree at Kyonggi University and a doctoral degree at the University of Nebraska-Lincoln. He has worked at PricewaterhouseCoopers as a certified public accountant in Seoul, South Korea. His area of interest is environmental management and service business. He is affiliated with professional societies including Academy of Management, Decision Science Institute, Pan-Pacific Conference, and Production and Operations Management Society.

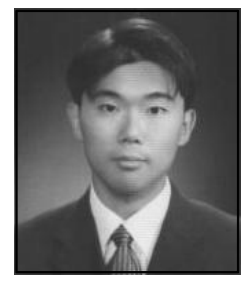

\section{Donghyun Choi}

Donghyun Choi is a visiting scholar at the Kansas State University. His research interests include supply chain management, open innovation, and green operations. His publications have appeared in management decision, International Journal of Information and Decision Sciences, and Industrial Management \& Data System. He received his Bachelor and Master of Business Administration from Yonsei University, Seoul, South Korea and a doctoral degree at the University of Nebraska-Lincoln. He is affiliated with professional societies including Academy of Management, Decision Science Institute, Pan-Pacific Conference, and Production and Operations Management Society.

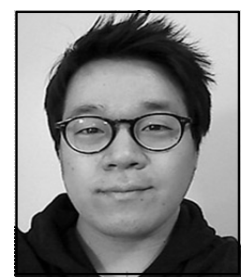

\section{Jin Sung Rha}

Jin Sung Rha is a doctoral candidate at Management Department, University of Nebraska-Lincoln. He received a Bachelor of Arts in education, a Bachelor of business administration degree from Yonsei University, Seoul, South Korea in 2008, and a Master of Arts in business administration degree from University of Nebraska-Lincoln, NE, USA in 2010. He published in Production and Inventory Management Journal and International Journal of Information and Decision Sciences. His research interests include supply chain management and technology innovation. He is affiliated with professional societies including Academy of Management, Decision Science Institute, Pan-Pacific Conference, and Production and Operations Management Society. 


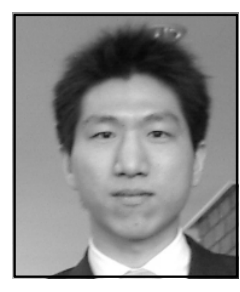

\section{Yongkee Suh}

Yongkee Suh has a B.A. and M.B.A from Yonsei University in South Korea. He worked as a consultant with Korea Logistics Association (KOLA). He is currently a section manager at Logisall, a logistics firm, specialized in logistics equipment and reverse logistics. His areas of research interest are supply chain management and supply contracts, reverse logistics and system dynamics. 